STUDENTS' PERCEPTIONS TOWARDS THE USE OF GOOGLE CLASSROOM FOR TEACHING ENGLISH TO GRADE X IN SMAN 1 AEK NATAS

AN ARTICLE

Submitted in Partial Fulfillment of the Requirements for the Degree of Sarjana Pendidikan

BY:

ANGGI PURWATI MUNTHE

Registration Number: 2163321003

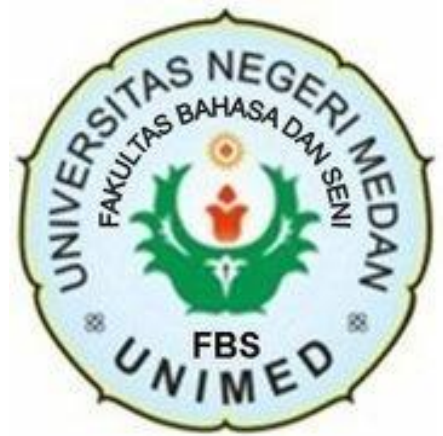

ENGLISH AND LITERATURE DEPARTMENT

FACULTY OF LANGUAGES AND ARTS STATE UNIVERSITY OF MEDAN 


\title{
STUDENTS' PERCEPTIONS TOWARDS THE USE OF GOOGLE CLASSROOM FOR TEACHING ENGLISH TO GRADE X IN SMAN 1 AEK NATAS
}

\author{
*Anggi Purwati Munthe \\ **Indra Hartoyo
}

\begin{abstract}
This study was aimed to investigate the student's perceptions towards the use of Google Classroom. The research was conducted at SMAN 1 Aek Natas. The research was descriptive qualitative research. The subject of this research was thirty-one students of SMAN 1 Aek Natas grade $\mathrm{X}$ have been using Google Classroom for teaching English. The results shows that Google Classroom is being helped for the students for study during this pandemic. Online learning can not completely replace conventional learning in the class but this system needs to be continuously developed for more effective learning.
\end{abstract}

Keywords: Students' perceptions, Google Classroom, English teaching.

\footnotetext{
*Graduate Status

** Lecturer Status
} 


\section{INTRODUCTION}

The development of information technology and the internet today does not only affect the electronic products but also the world of education, especially in the method of learning. Nowadays, integrating technology through the utilization of information and communication technology can control students learning and also more engaged in the class.

The adoption of online learning in education has several benefits, and several advantages. The use of technology through e-learning can help teacher to improve students' education and improve their technological skills.

Based on the researcher's observation with students' of grade $\mathrm{X}$ in SMAN 1 Aek Natas, it was found that there are some students' perceptions towards the use of Google Classroom. From the observation students said that it was a fun media that helped them for it's flexibility of place. Students didn't have to go to school every day. Google Classroom helped them easily to follow the lessons as usual anywhere. They became active because they felt free to comments in google classroom. Teacher active to send and give task and students can ask the teacher by personal chat. However there were some students who thought Google Classroom was not effective for learning experience because of the low of internet connection in the remote areas, so that some students could not acces the material of learning easily. The elearning method may be less effective than traditional methods of learning because of the lack of interaction or relation about students in online teaching, some students prefered the traditional method because they needed to know 
the body gesture and interaction in the classroom. The learning process is much easier face-to-face with instructors or teachers. Some students felt uncomfortable when they wanted to ask some questions because they wanted to know about the teacher's explanation directly. They also did not have enough experience with technology or they had no idea about using technology in the classroom because Google Classroom was unfamiliar with them. E-learning also can be subject to piracy, inadequate selection skills, plagiarism, and cheating and also may negatively impact socialization skills and limit the role of instructors as directors of the educational process.

E-learning can give solution in teaching learning processs, but the observation in this research showed that learning activities with technology is one of the new challenges in education because many students should struggle to integrate it for several reasons. Based on the problem above, the researcher would investigate the student's perception toward the use of Google Classroom for teaching English.

\section{THEORITICAL FRAMEWORK}

\section{a. E-learning in educational perspective}

E- learning is a combination of two words namely electronic and learning. Literally, e-learning is electronic learning or teaching and learning process carried out online. In practice, e-learning utilizes information technology as a learning tool. 
According to Agarwal \& Pandey (2012), e-learning focuses on the use of technology in learning and education. E-learning refers to the use of information and communication technology in the learning process which consists of electronic media.

E-learning is the use of new multimedia technologies and the internet to improve the quality of learning by facilitating access to resources and services, as well as remote exchange and collaboration (Alonso et.al.,2005).

\section{b. LEARNING MEDIA}

In general, learning media in education is called media, the various types of components in the student environment that can stimulate it to think (Gagne, in Budi 2011). Briggs (in Tryanto,(2013) states the media is any physical tool that can resent a message as well as stimulate students to learn. According to Musfiqon (2012) media is a tool used by teachers with designs tailored to improve the quality of learning. Learning media is materials, tools, or techniques used in teaching and learning activities with the intention that the process of interaction of educational communication between teachers and students can take place appropriately and efficiently.

\section{c. GOOGLE CLASSROOM}

Google Classroom is a tool which facilitates studsents and teacher collaboration; also the teacher can create and distribute assignment for students in an online classroomfor free (Beal, 2017). It makes teachers simply 
build groups to share assignments and announcements.Google Classroom can be a tool that makes learners become active participants.

It has learning features that make teachers create and handle assignment actively and also provide feedback to students. Google Classroom makes it easier for teachers to handle students' work. it is really needed for teachers and students because it is easy and simple to use.

\section{d. THE BENEFITS AND LIMITATIONS}

Google Classroom has copious facilities that beneficial for its users. A few of them are user-friendly, cost-free, cell phone friendly, and timesaving. using Google Classroom is really easy.

In spite of various benefits, Google Classroom also has some limitations. Some of them as mentioned by Pappas (2015) are limited integration options, too googlish, no automated updates, difficult learner sharing, and editing problems. It is difficult for a teacher to manage teaching materials and to set deadlines for assignments because of Google Calendar or any other calendar. Some of Google Classrooms' buttons are only familiar to Google users. It can make new users feeling confused or needing moretime to deal with it. That is why Pappas define Google Classroom too "googlish". There is no auto-update feature in Google Classroom. It makes learners miss an important announcement because they should refresh it regularly. 


\section{RESEARCH METHOLOGY}

This research deals with the online teaching and learning that focuses on the students' perception toward the use of Google Classroom. This research was conducted by a descriptive qualitative method. Sandelowski (2000) describes this qualitative descriptive method as one that provides a comprehensive summary in everyday terms, it is less transformational than methods such as phenomenology or grounded theory.

\section{RESEARCH FINDING AND DISCUSSION}

\section{a. The Technique Data Analysis}

The collected data were analyzed by doing the following steps: Identifying types of students' perceptions, classifying the students' perceptions into their types, counting the percentage of the students' perceptions, elaborating the students' perceptions and concluding the result of the study.

\section{b. Findings}

E-learning lacks physical interaction between students and their teachers and among students themselves as compared to a classroom setting. It mainly depends on student initiative and the students are responsible for their learning. The lack of interaction between teacher and students or even between students themselves.

1. E-learning lacks physical interaction between students and their teachers and among students themselves as compared to a classroom 
setting. It mainly depends on student initiative and the students are responsible for their learning. The lack of interaction between teacher and students or even between students themselves.

2. The lack of focus. However, the atmosphere at home is definitely different from school. There are things that can interfere with children's learning concentration. There are times when children are not focused on learning. The effect will have an impact on parents and various people's activities who are working. Disturbing voices and daily routine during class hours make them less focused and ignores academic aspects.

3. Changes in the teacher's role from initial mastery cconventional learning techniques are now also being required able to know learning techniques using ICT, some students feel bored and the role of the teacher is less effective because the teacher only distributes videos to students and asks comments and lacks practice in learning.

4. The effect of online learning makes some students stay at their homes in the hope of avoiding the corona virus.However, there are some areas where the availability of networks to access the internet has not been stable, and that then has an impact on the online learning process. 


\section{c. Discussion}

From the data shows that in terms of ease of access, most students feel that the existence of Google Classroom is helpful for them in sending and collecting assignments, making it faster and more efficient. Related to the previous studies conducted by Holmes and Gardner (2006) stated that the online learning as an inovation of learning. Positively the result of the study showed that the online learning used to solved educational problems in Indonesia.

The students are being helped in understanding the learning materials. Based on the data of usefulness perceptions, it has been show that most student understand the topic material provided by the teacher using Google Classroom. Meanwhile, the students' satisfaction in online learning is still considered poor. The main research is due to the limited interaction built in online learning such as teacher's inavaliability to give a direct instruction or correction to the students and less practical.

\section{CONCLUSION AND SUGGESTION}

\section{a. Conclusion}

Learning is the process of acquiring new understanding, knowledge, behaviors, skills, values, attitudes and preferences. Learning can take place in a traditional classroom setting and online learning. Traditional classroom setting, the student must be present in the classroom for every lesson meanwhile online learning is the process of studying without having to 
physically attending classes. Online learning more efficient by quickly being able to obtain information via the internet through the internet but because of the social distancing causes a lack of practice and interaction especially for this pandemic.

During this pandemic, the students' perceptions towards online learning especially, through Google Classroom shows a significant results. It can be seen from the result of the questionnaire that information about ease of access shows that $25(80.7 \%)$ of students agreed that using Google Classroom makes it easy for them to access the and $6(22.5 \%)$ of students thought that they had difficulty using google classrooms to access subject matter, this was due to some areas where there were frequent blackouts and weak internet signals.

Students perceptions towards the use of Google Classroom to sending and receiving assignment, it was obtained that 27 (87.0\%) of students thought that they found it easy to send and receive assignments given by the teacher, $2(6,5 \%)$ of students argue that they have difficulties to sending and receiving assignments due to unstable internet networks and $2(6.5 \%)$ of students partial agree, meaning that they agreed that Google Classroom helped in sending and receiving assignment but still have problem on the signal.

From the usefulness of the google classroom shows that $24(77.41 \%)$ of students think that they understand learning topics easily using google classroom. While $4(12.9 \%)$ thought that they had difficulty understanding this subject matter and $3(9.7 \%)$ of students partial degree. 
There are some of the benefits that can be felt by students while using Google Classroom in learning English, including: easier understanding of learning materials because of interesting learning media, easy access to learning and communication, timely filling in absences, efficient and effective, saving costs to school, increase vocabulary and can still learn from home even during a this pandemic.

In expressing their opinions when using Google Classroom the data shows that $19(61.2 \%)$ of students feel happy and comfortable in expressing their opinions because supported by comment feature. They are not nervous and also see other opinions, besides that there are 7 (25.8\%) of students who find it difficult to convey their , $3(9.7 \%)$ partial degree and $2(6.4 \%)$ of students were neutral, meaning that they never in expressing their opinions.

For the role of the teacher that is felt by students that $23(74.19 \%)$ of students think that the teacher has been effective in discussing through the Google Classroom, 4 (12.9\%) of students think that the teacher has not been effective in discussing using Google Classroom and 4 (12.9\%) of students partial agree.

The information about students' perceptions in satisfaction from the data shows that $100 \%$ of students from thirty one students chosen for conventional learning. They feel satisfy when studying in the classroom as they usually master deeper material, meet friends, interact and discuss directly, are more focused because there is no noise, can learn practical in class, pleasant classroom atmosphere, and there is no network problems. 
From the percentage of student motivation from thirty one of students which shows that $26(83.8 \%)$ of students feel motivated by this online learning and $3(9.67 \%)$ of students feel unmotivated due to network problems and teacher language which is sometimes difficult to understand because of the lack of interaction and $2(6.4 \%)$ partial degree.

Based on the data obtained, student's satisfaction towards online learning is still less than conventional one. This means this system is recommended to be developed.

\section{b. Suggestion}

English teacher in that school realize that teaching English use technology is important and also use different approaches and roles in based on information and communication technology process to increase the motivation of the students.

Other researcher, who will conduct similar research, this study is expected to help and give more information about students' perceptions towards the use of Google Classroom. 


\section{REFERENCES}

Agarwal, H.,\& Pandey, G. N. (2012). Impact of E-Learning in Education. International Journal of Science and Research(IJSR).

Alonso,F.,Lopez,G.,Manrique, D \& Vines, J.M(2005). An Instructional model for web-based e-learning education with a blended learning process approavh. British Journal of Educational Technology, 36(2),217-235.s

Budi Listiyono, 2011. Pengertian Multimedia Pembelajaran.(http://listiyonobudi. blogspot.com/2011/11).

Beal, V. (2017). Google Classroom. Retrieved April 25, 2017, from http;//www.webopedia.com/TERM/G/google-classroom.html.

Holmes, B. \& Gardner, J. (2006). E-Leraning: Concepts and Practice, London: SAGE Publications.

Musfiqon, 012. Pengembangan Media dan Sumber Pembelajaran Jakarta :Prenada Media.

Pappas, C. (2015), August 20). Google Classroom Review; Pross And Cons Of Using Google Classroom in eLearning from elearning industry.

Sandelowski, M. (2000). Focus on research methods: Whatever happened to qualitative description? Research in Nursing \& Health, 23, 334-340

Triyanto Eko dkk. (2013). Peran Kepemimpinan Kepala Sekolah dalam Pemanfaatan Media Pembelajaran Sebagai Upaya Peningkatan Kualitas Proses Pembelajaran, Jurnal Teknologi. 